\title{
SAPROBIC FUNGI AS BIOCONTROL AGENTS OF HALO BLIGHT (Pseudomonas syringae $p$ v. garcae) IN COFFEE CLONES
}

\author{
Dayana Alvarenga Botrel ${ }^{1}$, Marie Caroline Ferreira Laborde 2 , Flávio Henrique Vasconcelos de Medeiros ${ }^{3}$, \\ Mário Lúcio Vilela de Resende ${ }^{4}$, Pedro Martins Ribeiro Júnio ${ }^{5}$, Sérgio Florentino Pascholati ${ }^{6}$, \\ Luís Fernando Pascholati Gusmão ${ }^{7}$
}

(Received: November 13, 2017; accepted: April 02, 2018)

\begin{abstract}
Halo blight caused by Pseudomonas syringae pv. garcae is a limiting disease in coffee production. There are few efficient commercial products on the market to control this disease, and therefore, the prospection of different biocontrol agents is a promising alternative. The objectives in this study were (i) to select saprobic fungi with the potential to control halo blight in coffee clones, and (ii) to evaluate the contributions of induced resistance as control mechanisms. Plants were sprayed with Gonytrichum chlamydosporium, Phialomyces macrosporus, and Moorella speciosa $7 \mathrm{~d}$ before inoculation with Pseudomonas. syringae pv. garcae. The area under the halo blight progress curve (AUDPC) and plant growth parameters were evaluated. $M$. speciose and G. clamydosporium did not reduce the AUDPC and even reduced plant growth in none of the trails compared to the water control. P. macrosporus consistently reduced AUDPC by $42-72 \%$ and increased plant height by $40 \%$. Thereafter, the contributions of induced resistance was evaluated for the P. macrosporus, selected as the most promising biocontrol agent.. In order to determine induced resistance, phenylalanine ammonia lyase (PAL), peroxidase (POX), and ascorbate peroxidase (APX) activity of plant leaves were measured at two time points after stress challenge. Enzyme activity evaluation demonstrated high activity of POX and PAL at seven days after treatment with the saprobe, and high APX activity after 14 days. The results of this study indicate that $P$. macrosporus has the potential to be used in the management of coffee halo blight in seedling production, and one mechanism likely involved is induced resistance.
\end{abstract}

Index terms: foliar disease, Induced systemic resistance, Coffea arabica, saprobe fungus, biological control.

\section{FUNGOS SAPRÓBIOS COMO AGENTES DE BIOCONTROLE DA MANCHA AUREOLADA DO CAFEEIRO}

RESUMO: A mancha aureolada causada por Pseudomonas syringae pv. garcae é uma doença limitante na produção de café. Há poucos produtos comerciais eficientes no mercado para controle desta doença e, portanto, a prospecção de diferentes agentes de biocontrole é uma alternativa promissora. Os objetivos deste estudo foram: (i) selecionar fungos sapróbios com o potencial de controle da mancha aureolada em clones de café, e (ii) avaliar a contribuição da indução de resistência como mecanismo de ação. Plantas foram pulverizadas com Gonytrichum chlamydosporium, Phialomyces macrosporus e Moorella speciosa 7 dias antes da inoculação com $P$. syringae pv. garcae. A área abaixo da curva de progresso da mancha aureolada (AACPMA) e variáveis relativas ao crescimento foram avaliadas. M. speciose e G. clamydosporium não reduziram a AACPMA em nenhum dos ensaios quando comparado à testemunha. P. macrosporus reduziu a AACPMA em $42-72 \%$ e aumentou a altura de plantas em $40 \%$. Em seguida foi avaliada a indução de resistência como possível mecanismo de ação exercido por $P$. macrosporus, selecionado como o agente de biocontrole da mancha aureolada mais promissor. Para determinar a indução de resistência, as atividades das enzimas fenilalanina ammonia liase (PAL), peroxidase (POX) e ascorbato peroxidase (APX) de folhas tratadas e inoculadas em amostragens aos 7 e 14 dias após o tratamento. A avaliação da atividade de enzimas demonstrou atividade de POX e PAL aos sete dias, e atividade de APX aos 14 dias após tratamento com o sapróbio. Os resultados deste estudo indicam que $P$. macrosporus tem potencial de ser usado no manejo da mancha aureolada do cafeeiro na produção de mudas, e o mecanismo provavelmente envolvido nesta proteção é a indução de resistência.

Termos para indexação: Doença foliar, Indução da resistência sistêmica, Coffea arabica, Fungos sapróbios.

\section{INTRODUCTION}

Brazilian coffee has an important contribution to global trade in commodities (AGRICULTURE, 2016). However, several factors could contribute to the reduction of grain yield. One of them is losses due to diseases such as coffee rust, cercospora leaf spot, anthracnose, and halo blight caused by Pseudomonas syringae pv. garcae (BELAN et al., 2016). Recently, severe epidemics of halo blight have been reported as a limiting factor in coffee cultivation in cooler and

1,2,3,4Universidade Federal de Lavras/UFLA - Departamento de Fitopatologia/DFP - Cx. P. 3037 - 37.200-000 - Lavras - MG dayanabotrel@yahoo.com.br, marielaborde89@hotmail.com, flaviomedeiros@dfp.ufla.br, mlucio@dfp.ufla.br

${ }^{5}$ Embrapa Semiárido - Rodovia BR 428, Km 152, s/n - Zona Rural - 56.302-970 - Petrolina - PE - pedro.ribeiro@embrapa.br ${ }^{6}$ Universidade de São Paulo - Escola superior de Agricultura Luiz de Queiroz - Departamento de Fitopatologia e Nematologia - Avenida Pádua Dias, 11 - 13.418-900 - Piracicaba - SP - sfpascholati@usp.br

${ }^{7}$ Universidade Estadual de Feira de Santana - Departamento de Ciências Biológicas - Av. Transnordestina, s/n - 44.036 -900

Feira de Santana - BA - lgusmao@uefs.br

Coffee Science, Lavras, v. 13, n. 3, p. 283 - 291, jul./sep. 2018 
more windswept regions, in forming or newly pruned crops, and in nurseries (PEIXOTO et al., 1999; SERA et al., 2002, 2004; ZOCCOLI et al., 2011).

Regarding the control of halo blight, there are few control strategies with proven management effectiveness (RODRIGUES et al., 2012). While no resistant cultivar is still available, the plant immune system can be boosted up through induced resistance, namely pathogenassociated molecular pattern-triggered immunity (RODRÍGUEZ et al., 2016). This mechanism is employed for the management of plant bacterial diseases (LLORENS, 2015) and result in the disease control or at least the delay of disease onset (ATHAYDE SOBRINHO et al., 2005; NOJOSA et al., 2005). Induced resistance (IR) in plants can be obtained through plant spray of biotic (plant extracts, microorganisms or their metabolites) or abiotic (chemical substances) compounds (CAVALCANTI et al., 2005). Several studies have proved the effectiveness of both chemical and biological products (MARTINS et al, 2013). One of the most used resistance abiotic inducer is Acibenzolar-S-methyl (ASM) which was also the first resistance inducer approved for commercial use (LYON; NEWTON, 1997 ; ZHANG, 2016). Since then, many products have been developed with a similar mode of action, some of them based on the use of living microorganisms or their derivatives (RESENDE et al., 2006). This control strategy is a promising tool to enhance the defensive capacity of plants providing long-term systemic resistance to a broad spectrum of pests and can be used in the integrated management of plant diseases (WALLING, 2001).

Microorganisms used to induce resistance can mobilize various strategies, including the production of elicitor molecules and their own structural components (BASHAN et al., 2016; SPADARO; DROBY, 2016). In addition, the use of microorganisms in disease management can tackle the disease through a hallmark of mechanisms: induced resistance, antibiosis, parasitism and competition, which culminates in disease control and in greater vigor and plant yield (MOYA-ELIZONDO et al., 2016; WANG et al., 2015). Another important advantage is the use in both organic and conventional agriculture, ensuring the commercial success of products generated from these fungi when used alone or in combination (KÖHL, 2015; OKON LEVY, 2015; ROMANAZZI, 2016). In the past few years, saprobic fungi have received increasing attention, not only for improving and preserving the quality of the coffee beverage as the commercial product called Cladosporin ${ }^{\circledR}$ (active ingredient Cladosporium cladosporioides (Fresen.) G.A. de Vries), but also as a potential bioagent for controlling coffee diseases (ANGELICO et al., 2017). As a consequence, the adoption of saprobic fungi for disease management in coffee is highly increasing, especially, due to the efficient disease control under adverse conditions (KÖHL et al., 1995, 2011).

Saprobe fungi are able to overwinter in the crop stubble and therefore withstand sudden variations in temperature and humidity (KÖHL et al., 1995), environmental impounds to microbioal establishment commonly encountered in the phylloplane, also a niche for $P$. syringae pv. garcae Amaral, Teixeira \& Pinheiro. One such fungi, Phialomyces macrosporus Misra \& Talbot, has previously been reported as fast-growing fungus that displaces Colletotrichum gloeosporioides from coffee leaves (RODRIGUEZ et al., 2016) and a possible endophyte of coffee plants (AHMAD et al. 2003).

A collection of saprophytic fungi isolated from leaf litter of an arid region of Brazil has proven to be efficient to control plant disease. Some of these isolates is a potential agent of biocontrol in coffee (RODRÍGUEZ et al., 2016), white mold in soybean (Barros et al., 2015) and brown eye spot (Laborde et al., 2018). However, the saprobe fungi potential for bacterial blight control has not been attempted for many species. The objectives of this study were (i) to select saprobic fungi with potential to control halo blight in coffee clones, and (ii) to evaluate induced resistance as the possible control mechanisms of the most promising biocontrol agent.

\section{MATERIALS AND METHODS}

\section{Seedling production}

Coffee clone seeds (Mundo Novo IAC 3764 and Red Catuaí cultivars) were obtained from Agricultural Research Company of Minas Gerais (EPAMIG) and sown in trays containing sand. After the cotyledonary leaves stage, seedlings were transplanted into 2 L-bags. Soil and sand were used for the substrate in a 3:1 ratio, fertilized using super phosphate and NPK 04-14-08 added to the mixture. The seedlings were kept in the greenhouse at 25-28 during the entire experiment. 


\section{Saprobic fungi isolates}

Three saprobe fungal strains were used in this study: P. macrosporus, Gonytrichum chlamydosporium G.L. Barron \& G.C Bhatt and Moorella speciosa Rao \& Rao obtained from the Culture Collection of the Microorganisms from Bahia, Feira de Santana State University (Bahia, Brazil).

They were grown in a medium of cornmeal carrot agar (CCA) for $7 \mathrm{~d}$ at $27^{\circ} \mathrm{C}$. One disc $(7$ $\mathrm{mm}$ ) containing conidia and mycelium was suspended in $100 \mathrm{~mL}$ of CCA liquid medium, grown in an orbital shaker at $120 \mathrm{rpm}$ and $27^{\circ} \mathrm{C}$. The suspension was shredded, homogenized in a blender and adjusted to $3.4 \times 10^{7} \mathrm{CFU} \mathrm{x} \mathrm{mL}{ }^{-1}$. Antagonistic fungi were inoculated by spraying the leaves until run off.

\section{Pseudomonas syringae pv. garcae}

The isolate of $P$. syringae pv. garcae was obtained from the Microorganism Collection of the Laboratory of Plant Bacteriology, Universidade Federal de Lavras (UFLA). For all experiments, the pathogen was cultivated in Kado 523 liquid medium (MB1) (KADO; HESKETT, 1970) for 48 hours in an orbital shaker at $24^{\circ} \mathrm{C}$ and $90 \mathrm{rpm}$. Bacterial concentration used, was approximately $0.5\left(\mathrm{OD}_{600 \mathrm{~nm}}\right)$ corresponded to $3.4 \times 10^{7} \mathrm{CFU} \mathrm{x}$ $\mathrm{mL}^{-1}$. Bacterial pathogenicity was ensured before the installation of each essay, through inoculation in coffee plants followed re-isolation of the pathogen.

\section{Disease prevention control screening}

Each saprophytic fungus was sprayed until runoff onto 7-month-old coffee seedlings $7 \mathrm{~d}$ before the pathogen's inoculation. The inoculation of $P$. syringae pv. garcae on leaves was done by spraying the entire leaf until run-off. Plastic bags were placed $2 \mathrm{~d}$ before and after the inoculation, to simulate a moist micro-chamber. The chemical compound Acibenzolar-S-methyl $\left(0.05 \mathrm{~g} \mathrm{~L} \mathrm{~L}^{-1}\right)$ was included as a positive control for induced resistance and distilled water as a negative control in the initial screening step and evaluation of induced resistance potential, since such product compound is a putative resistance inducer against plant disease in coffee (RODRIGUEZ et al., 2016).

Plants were assessed for disease severity and plant growth at 7, 14, 21, 28 and $35 \mathrm{~d}$ after $P$. syringae pv. garcae inoculation. The disease rating was carried out using the diagrammatic scale adapted from SIDHU AND WEBSTER scale (1977). In all experiments, plants were distributed in a randomized block design with three replicates and two seedlings per plot. The experiment was performed twice. P. macrosporus was the fungus with the highest potential for disease reduction and its mode of action was further studied.

\section{Defense-related enzyme activity}

The fifth pair of leaves of 7-month-old coffee seedlings was used in these assays (FERNANDES et al., 2014). Seven days before pathogen inoculation, suspensions of $P$. macrosporus, ASM and water were sprayed on the seedlings. The leaves were stored in aluminum foil, quickly frozen in liquid nitrogen $\left(\mathrm{N}_{2}\right)$ and then stored in an ultrafreezer at $-80^{\circ} \mathrm{C}$ for subsequent analysis. The plants were distributed in a randomized-block design with three replicates and two seedlings per plot. Treatments were: i) Water $+P$. syringae pv. garcae; ii) ASM $+P$. syringae pv. garcae; iii) $P$. macrosporus $+P$. syringae pv. garcae. Leaves samples of each plant were collected at 7 and 14 $\mathrm{d}$ after treatments to determine the activities of defense enzymes.

\section{Ascorbate peroxidase - APX}

To obtain the extracts used for determining the activity of APX and guaiacol peroxidase (POX), 0.2 -g leaf tissue samples were added to liquid $\mathrm{N}_{2}$ and polyvinylpyrrolidone (PVP) $(1 \% \mathrm{w} / \mathrm{v})$ and ground with mortar and pestle to a fine powder. The powder was homogenized with $1300 \mu \mathrm{L}$ of extraction buffer $(400 \mathrm{mM}$ potassium phosphate, pH 7.8; 10 mM EDTA; $200 \mathrm{mM}$ ascorbic acid; water). The homogenate was centrifuged at 14,000 $\times g$ for 25 min at $4^{\circ} \mathrm{C}$, and the supernatant was used for enzymatic determination. The supernatant $(20$ $\mu \mathrm{L}$ ) from each sample was added to three wells of an ELISA plate (UV plate). Then, incubation buffer (200 mM potassium phosphate, $\mathrm{pH} 7.0 ; 10$ $\mathrm{mM}$ ascorbic acid; $2 \mathrm{mM}$ hydrogen peroxide and water) was added to the wells. Absorbance was measured at $290 \mathrm{~nm}$ in the ELISA plate for $3 \mathrm{~min}$ after the addition of the extract to the mixture, with readings taken every $15 \mathrm{~s}$. The temperature at the reading was $25^{\circ} \mathrm{C}$. A molar extinction coefficient of $1.4 \mathrm{mM}^{-1} \mathrm{~cm}^{-1}$ was used to calculate APX activity, which was expressed in $\mu \mathrm{m}$ produced per min $\mathrm{mg}^{-1}$ of protein.

\section{Guaiacol peroxidase - POX}

A $40-\mu \mathrm{L}$ aliquot of supernatant from each sample was added to three wells of the 
ELISA plate. Then, reaction buffer $(100 \mathrm{mM}$ potassium phosphate, $\mathrm{pH} 7.0 ; 50 \mathrm{mM}$ guaiacol and $125 \mathrm{mM}$ hydrogen peroxide) was added to the wells. Absorbance was measured at $420 \mathrm{~nm}$ in the ELISA plate for 2 min (reading every 15 s) after addition of the extract to the mixture. The temperature at the reading was $30^{\circ} \mathrm{C}$. The molar extinction coefficient of $2.47 \mathrm{mM}^{-1} \mathrm{~cm}^{-1}$ was divided by two (1.235) and used to calculate POX activity (CHANCE; MAEHLEY, 1955), which was expressed in $\mu \mathrm{m}$ produced per min $\mathrm{mg}^{-1}$ of protein.

\section{Phenylalanine ammonia-lyase - PAL}

Phenylalanine ammonia lyase (PAL) activity was measured according to MORI et al. (2001). For each gram of macerated sample, $3 \mathrm{~mL}$ of extraction buffer $(50 \mathrm{mM}$ sodium phosphate, pH 6.5; 1 mM PMSF; 1\% PVP) was added. A reaction mixture was prepared by combining Tris$\mathrm{HCl}$, buffer, $\mathrm{pH} 8.8,40 \mathrm{mM}$ phenylalanine and 5 $\mu 1$ of enzyme extract. The reaction mixture was incubated for $20 \mathrm{~min}$ (reading every two minutes) at $37^{\circ} \mathrm{C}$, and readings were taken at $280 \mathrm{~nm}$. The values are expressed in $\mu \mathrm{m}$ produced per min $\mathrm{mg}^{-1}$ of protein.

\section{Total protein}

Soluble protein concentration was measured using a standard bovine serum albumin (BSA) curve as used by BRADFORD (1976).

\section{Experimental design and statistical ana lysis}

In all experiments, we used a randomized complete block design, with three blocks and one pot per plot with two seedlings per plot. The data were submitted to an analysis of variance (ANOVA), and Tukey's test $(\mathrm{P}=0.05)$. At the end of the experiment (five weeks), the AUDPC was calculated using the formula proposed by SHANNER; FINNEY (1977):

$$
\text { AUDPC }=\sum_{i=1}^{n-1} \frac{\left(Y_{i}+Y_{i+1}\right)}{2} *\left(T_{i+1}-T_{i}\right)
$$

where AUDPC $=$ area under the disease progress curve, $\mathrm{Yi}=$ proportion of disease in the $\mathrm{i}$-the observation, $\mathrm{Ti}=$ time in days in the $\mathrm{i}$-th observation, and $\mathrm{n}=$ total number of observations.

\section{RESULTS AND DISCUSSION}

The saprophytic fungus $P$. macrosporus reduced the disease severity $(P=0.0001)$ as compared to the control with the pathogen alone (FIGURE 1). In the first experiment, treatment with $P$. macrosporus reduced the AUDPC by $42 \%$ and even with the presence of the pathogen, increased the vegetative seedling growth in $40 \%$ $(P=0.03)$ (FIGURE 2). However, $M$. speciosa and $G$. chlamydosporium favored the development of disease, increasing AUDPC, as compared to controls. In addition, these fungi also reduced the seedling height $(P=0.03)$ (FIGURE 1 and 2). ASM neither reduced the AUDPC nor increase the plant height. In the second experiment, P. macrosporus reduced the AUDPC in $72 \%$ as compared to the control with $P$. syringae pv. garcae $(P=0.000)$.

In the biocontrol interactions, there are four most reported modes of actions: antibiosis, induced resistance, competition for nutrients or space and parasitism, all of which has been studied by Rodriguez et al. (2016). We selected $P$. macroscopus among 10 saprophytic fungi for its higher activity against $C$. gloeosporioides in coffee seedlings and determined induced resistance and competition for nutrients as possible modes of action. Although, competition is reported as a mode of action of bacterial diseases, fungi do not play such role, this is a plausible mode of action for bacterial antagonists (BENEDUZI et al., 2012) and to the best of our knowledge there is not report of fungal antagonists that displace a bacterial pathogen due to the faster-growing nature of the pathogen and the co-evolution with the plant host to fast invade the plant tissue.

The same authors mentioned above using the same saprobes obtained similar control of anthracnose (C.gloeosporioides) in coffee seedlings. The protection against both fungal and bacterial diseases, both with necrotrophic-based parasitism is an indication that induced resistance may play a role in the plant protection, since the induced resistance follows the jasmonate pathway (THALER et al., 2004) which is in turn triggered by biotic elicitors such as biocontrol fungi (LORITO et al., 2010).

The induced resistance involved many pathways that are either exclusively regulated by the jasmonate pathway or other secondary messengers. In regard to the phenylpropanoid pathway we have studied the activity of an upstream enzyme, the phenylalanine ammonia lyase (PAL). The effect of PAL activity was significant for both evaluation periods $(P=0.003$ and 0.016). 


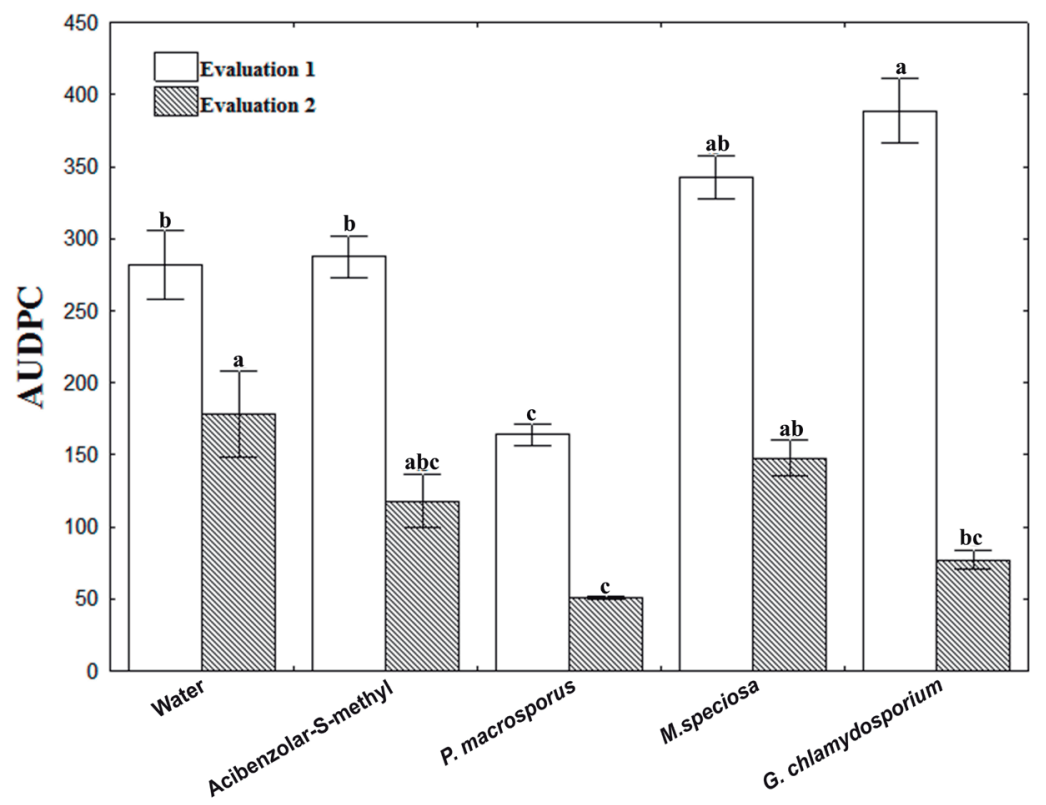

Treatments

FIGURE 1 - Screening of saprophytic fungi against $P$. syringae pv. garcae on coffee seedlings. Seven-month-old coffee seedlings were sprayed with the antagonists and $P$. syringae pv. garcae was applied $7 \mathrm{~d}$ later and disease severity was assessed to calculate the area under the disease progress curve (AUDPC). The graph represents two equal experiments conducted in different periods. The bars with the same letter are similar at the $5 \%$ level according to the Tukey's test multiple range test. $\mathrm{CV}=11.40 \%$ and $22.83 \%$, respectively. The line on each bar represents $\pm \mathrm{SE}$.

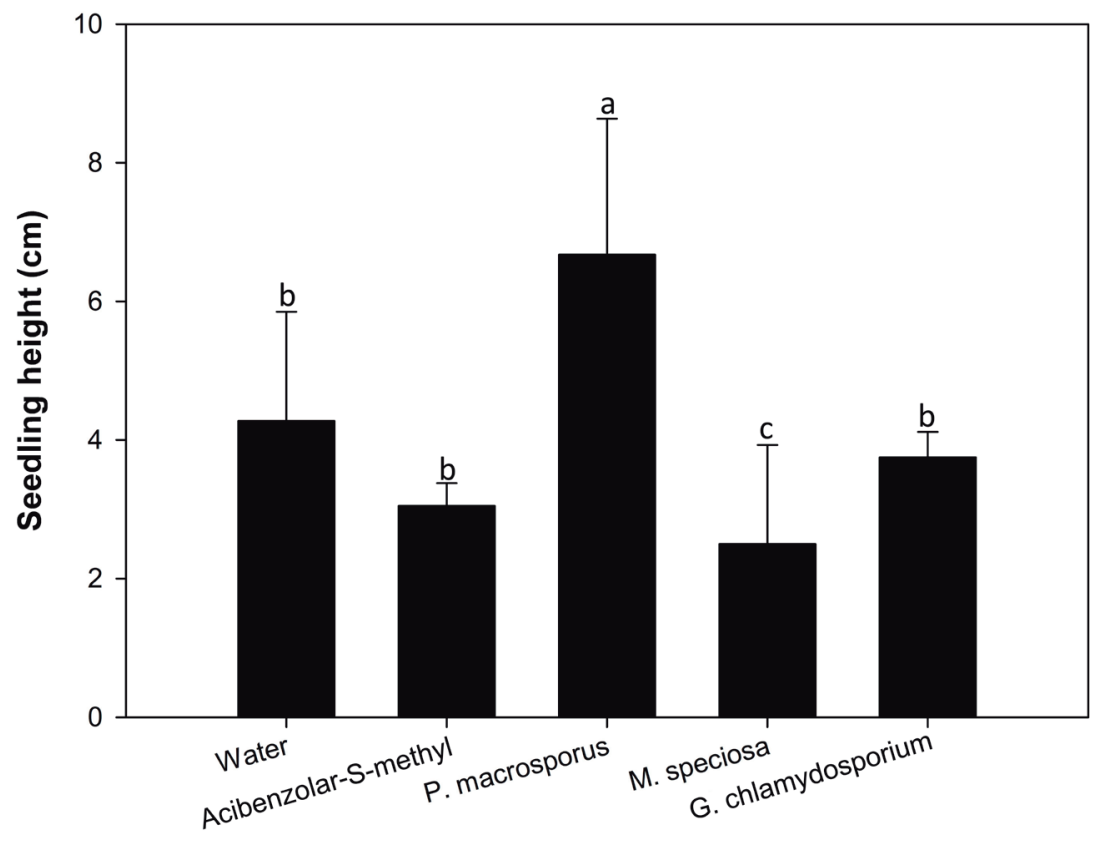

Treatments

FIGURE 2 - Plant height of coffee seedlings after application of five treatments. The bars with the same letter are similar at the $5 \%$ level according to the Tukey' multiple range test. $\mathrm{CV}=32.87$. The line on each bar represents $\pm \mathrm{SE}$. 
At seven days after treatment, $P$. macrosporus increased PAL activity as compared to the water control, and this effect was similar to the chemical resistance inducer, ASM (FIGURE 3 A). While at 14 days, PAL activity declined in all treatments.

During the induced defense, the peroxidases play a role in modulating the production of reactive oxygen species (ROS). In this study, at seven days POX activity (FIGURE 3B) increased up to 20 mol mL ${ }^{-1} \mathrm{~s}^{-1} \mathrm{mg}$ of protein in plants treated with $P$. macrosporus, corresponding to $95 \%$, and to $50 \%$ when compared to positive and negative controls, respectively $(P=0.001)$. At 14 days, treatment with $P$. macrosporus resulted in the enzyme activity similar to water control and lower than ASM $(P=0.021)$ (FIGURE 3 B). Regarding APX activity, at seven days, there was no difference among treatments $(P=0.26)$. While at 14 days, $P$. macrosporus treatment resulted in higher activity than the other treatments $(P=0.008)$, while ASM was similar to the water control (FIGURE $3 \mathrm{C}$ ).

In this study, at the time of bacterial inoculation, higher Phenylalanine ammonia-lyase $(\mathrm{PAL})$ and Guaiacol peroxidase (POX) responses were observed. A later enhancement of the activity of APX was observed in plants treated with the antagonist. This finding is in agreement with the study of Rodríguez et al (2016), who showed that the application of $P$. macrosporus increased the permeability of the cuticle followed by increased activities of guaiacol and phenylalanine ammonialyase (PAL) reducing anthracnose severity by 32 to $41 \%$. Thus, in our study treatments with $P$. macrosporus activated defense enzymes, balanced the content of $\mathrm{O}_{2}-$ and $\mathrm{H}_{2} \mathrm{O}_{2}$ and induced the disease resistance. As P. macrosporus is reported as endophytic of coffee seeds, it suggests this characteristic may ensure longer-lasting plant protection (HARMAN 2000; AHMAD et al. 2003). Although, future studies are necessary to evaluate the necessity for the reapplication at 7-d intervals or a formulation to foster the antagonist survival and activity over the 7-d period.

One strategy that may be involved in the induction of plant defenses is the production of pectolytic enzymes. These enzymes can hydrolyze components of the middle lamella of the plant, releasing oligogalacturonides, which are recognized by plant and trigger defense response (L'HARIDON, 2011). In agreement with our hypothesis, DURAN-FLORES AND HEIL (2014) studied the response of common bean (Phaseolus vulgaris $\mathrm{L}$.) to the application of leaf homogenate, as a source of DAMPs.
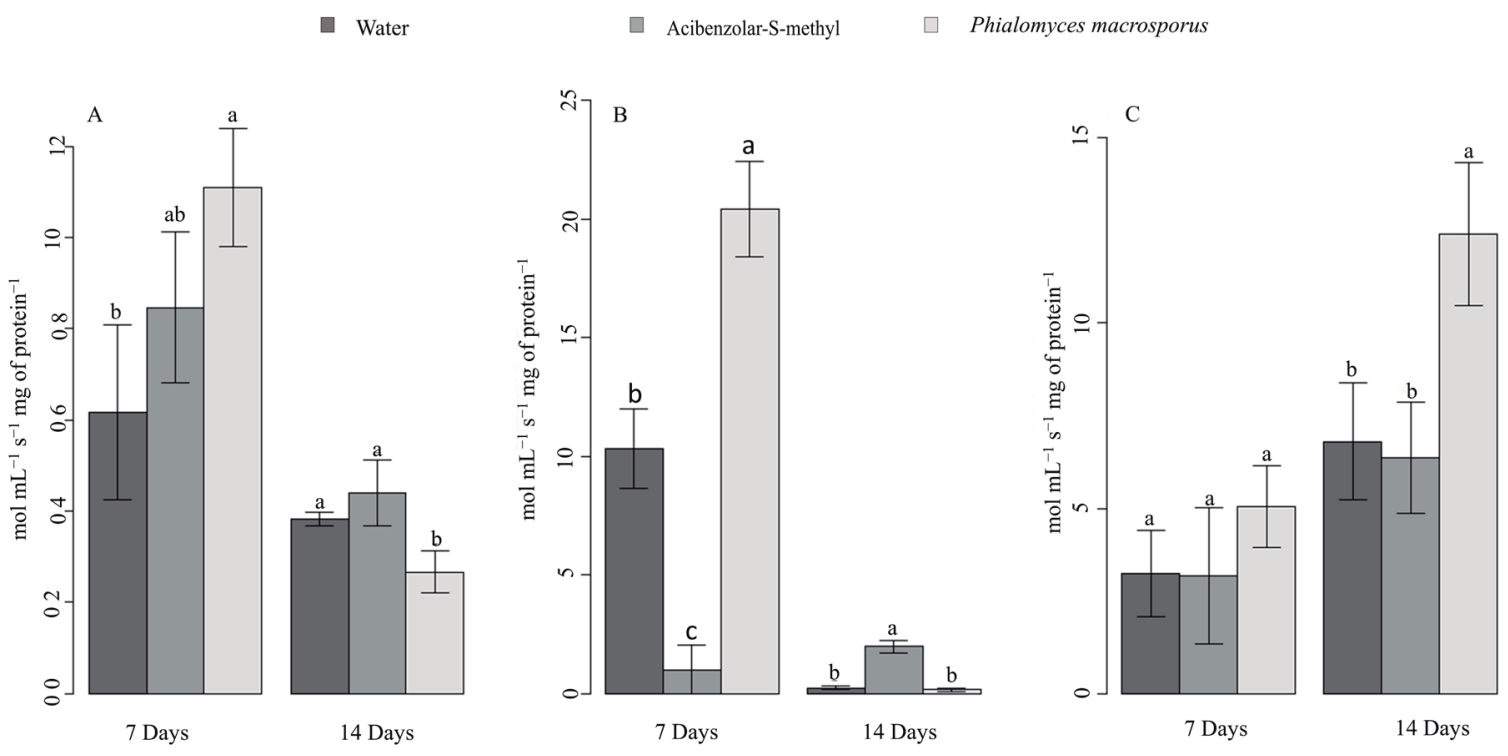

FIGURE 3 - Enzyme activities ( $\mathrm{mol} \mathrm{mL}^{-1} \mathrm{~s}^{-1} \mathrm{mg}$ of protein ${ }^{-1}$ ) after treatments applications. (A) Phenylalanine ammonia-lyase; (B) ascorbate peroxidase and (C) guaiacol peroxidase; Letters indicate differences between treatments detected by one way ANOVA in each sampling time (7 and $14 \mathrm{~d})$. The bars with the same letter are similar at the $5 \%$ level according to the Tukey' multiple range test $(P \leq 0.05)$. CV $=21.73 \%, 13.98 \% ; 10.91 \%$, $71.99 \%, 36.83 \%$ and $19.75 \%$ for graphs $\mathrm{A}, \mathrm{B}$, and $\mathrm{C}$, at 7 and $14 \mathrm{~d}$, respectively. 
The authors showed that the use of this oligogalacturonides resulted in ROS signaling and reduction of bacterial pathogen infection, $P$. syringae pv. garcae.

Foliar application of $P$. macrosporus to coffee seedlings $7 \mathrm{~d}$ before the inoculation of $P$. syringae pv. garcae increased activities of PAL, POX and APX, consistent with the induced resistance phenomenon. Similar studies showed that the resistance inducer requires time before pathogen application to trigger defense responses (MEDEIROS et al. 2011). Ahmad et al. (2014) working with biocontrol of early blight in tomato (Alternaria alternata (Fr.) Keissler), observed that when the antagonist Penicillium oxalicum was applied ten days before pathogen inoculation, tomato innate antifungal resistance boosted up and remarkably controlled disease incidence.

\section{CONCLUSION}

P. macrosporus has the potential to be used in the management of coffee halo blight in seedling production, and its mechanism of action is linked to the activation of plant defense responses.

\section{ACKNOWLEDGEMENTS}

The authors would like to thank the Brazilian National Council for Research and Technological Development (CNPq) for providing assistantship to the authors and National Institute of Coffee Science and Technology (INCT-Café) and SISBIOTA-FAPESP for providing financial support for the performed experiments.

\section{REFERENCES}

AGRICUlTure USDA. Production, Supply and Distribution. Available on : <http:/www.fas.usda.gov/ commodities/coffee>. Access in 16 Dec. 2017

AHMAD, R. B.; THARAPPAN, D. R.; BONGIRWAR. Impact of gamma irradiation on -the monsooning of coffee beans. Journal of Stored Products, Helsingin, v. 39, n. 2, p. 149-157. July. 2003.

AHMAD, A.; SHAFIQUE, S.;AKRAM, W. Penicillium oxalicum directed systemic resistance in tomato against Alternaria alternata. Acta Physiologiae Plantarum, Kraków, v. 36, n. 5, p. 1231-1240, May. 2014.

ANGELICO, C. L.; CHALFOUN, S.M.; REZENDE, M.L.V. Hiperparasitism on mycotoxigenic fungus Aspergillus ochraceus G. Wilh. by Cladosporium cladosporioides (Fresen) de Vries. International journal of environmental \& agriculture research, v. 3, n.11, p. 14, Nov. 2017.

ATHAYDE SOBRINHO, C. P. T.; FERREIRA, L. S., CAVALCANTI, L. S. Indutores abióticos. In: Indução de resistência em plantas a

patógenos e insetos. 1 ed. Piracicaba: Fundação de Estudos Agrários “Luiz de Queiroz", 2005. p. 51-80.

BARROS, D. C. M. et al. Biocontrol of Sclerotinia sclerotiorum and white mold of soybean using saprobic fungi from semi-arid areas of Northeastern Brazil. Summa Phytopathologica, Botucatu, v. 41, n. 4, p. 251-255, Dec. 2015.

BASHAN, Y.; DE BASHAN, L. E.; PRABHU, S. R. Superior polymeric formulations and emerging innovative products of bacterial inoculants for sustainable agriculture and the environment. In: - Agriculturally Important Microorganisms. Singapore: Springer Singapore, 2016. p. 15-46.

BELAN, L. L. et al. Occurrence of' Pseudomonas syringae pv. garcae'in coffee seeds. Australian Journal of Crop Science, Melbourne, v. 10, n. 7, p. 1015, July. 2016.

BENEDUZI, A. et al. Plant growth-promoting rhizobacteria (PGPR): their potential as antagonists and biocontrol agents. Genetics and molecular biology, São Paulo, vol. 35, n. 4, Jan. 2012.

BRADFORD, M. M. A rapid and sensitive method for the quantification of microgram quantities of protein utilizing the principle of protein-dye binding. Analytical Biochemistry, Valhalla, v. 72, n. 1-2, p. 248-254, May. 1976.

CAVALCANTI, L. S. et al. Indução de resistência em plantas contra patógenos e insetos. 1 ed. Piracicaba : Fealq, 2005. 263pp.

CHANCE, B. ; MAEHLEY, A. C. Assay of catalases and peroxidases. Methods in Enzymology, Baltimore: Christine Ziegler, 1955. 764-775p.

DURAN-FLORES, D.; HEIL, M. Damaged-self recognition in common bean (Phaseolus vulgaris) shows taxonomic specificity and triggers signaling via reactive oxygen species (ROS). Frontiers in plant science, Rockville Pike, v. 5, p. 585, Oct. 2014 
FERNANDES, L. H. M. et al. Inductors of resistance and their role in photosynthesis and antioxidant system activity of coffee seedlings. American Journal of Plant Sciences, Rockville Pike, v. 5, n. 25, p. 37103716, Dec, 2014

HARMAN, G. Myths and dogmas of biocontrol: changes in perceptions derived from research on Trichoderma harzianum T-22. Plant Disease, Saint Paul, v. 84, n. 4, p. 377-393, Apr. 2000.

KADO, C. I.; HESKETT, M. G. Selective media for isolation of Agrobacterium, Corynebacterium, Erwinia, Pseudomonas and Xanthomonas. Phytopathology, Saint Paul, v. 60, n. 6, p. 969-976. Jan. 1970

KÖHL, J. et al. Effect of interrupted leaf wetness periods on suppression of sporulation of Botrytis allii and $B$. cinerea by antagonists on dead onion leaves. European Journal of Plant Pathology, Wageningen, v. 101, n. 6, p. 627-637, Nov. 1995.

KÖHL, J. et al. Stepwise screening of microorganisms for commercial use in biological control of plant-pathogenic fungi and bacteria. Biological Control, Wageningen, v. 57, n. 1, p. 1-12, Apr. 2011.

KÖHL, J.; SCHEER, C.; HOLB, I. J. Toward an integrated use of biological control by Cladosporium cladosporioides H39 in apple scab (Venturia inaequalis) management. Plant Disease, Saint Paul, v. 99, n. 4, p. 535-543, Apr, 2015.

LABORDE, M. C. F. Avaliação de fungos sapróbios na sobrevivência de Cercospora coffeicola. 2014. 48 p. Dissertação (Thesis in Agronomy/ Plant disease) Universidade Federal de Lavras, Lavras, 2014.

L'HARIDON, F. et al. Permeable cuticle is associated with the release of reactive oxygen species and induction of innate immunity. PLoS Pathogens, San Francisco, v. 7, n. 7, p. 1-17, July. 2011.

LLORENS, E. et al. Induced resistance in sweet orange against Xanthomonas citri subsp. citri by hexanoic acid. Crop Protection, Amsterdam, v. 74, p. 77-84, April. 2015.

LORITO, M. et al. Translational research on Trichoderma: from 'omics to the field. Annual review of phytopathology, Palo Alto, v. 48, p. 395-417, May. 2010.

LYON, G. D.; NEWTON, A. C. Do resistance elicitors offer new opportunities in integrated disease control strategies?. Plant Pathology, Edgmond, v. 46, n. 5, p. 636-641, Oct. 1997.
MARTINS, S. J. et al. Biological control of bacterial wilt of common bean by plant growth-promoting rhizobacteria. Biological Control, Wageningen, v. 66, n. 1, p. 65-71, July. 2013.

MEDEIROS, F. H. V. et al. Transcriptional profiling in cotton associated with Bacillus subtilis (UFLA 285) induced biotic-stress tolerance. Plant and Soil, Wageningen, v. 347, n. 1-11, p. 327-337, June. 2011.

MORI, T.; SAKURAI, M.; SAKUTA, M. Effects of conditioned medium on activities on PAL, CHS, DAHP synthase (DS-Co and DS-Mn) and anthocyanin production in suspension cultures of Fragaria ananassa. Plant Science, Chicago, v. 160, n. 2, p. 355360, Dec. 2001

MOYA-ELIZONDO, E. A.; JACOBSEN, B. J. Integrated management of Fusarium crown rot of wheat using fungicide seed treatment, cultivar resistance, and induction of systemic acquired resistance (SAR). Biological Control, Wageningen, v. 92, p. 153163, Jan. 2016.

NOJOSA, G. B. A.; RESENDE, M. L. V.; RESENDE, A. V. Uso de fosfitos e silicatos na indução de resistência. In: CAVALCANTI, L. S. Indução de resistência em plantas a patógenos e insetos. Piracicaba: Fundação de Estudos Agrários “Luiz de Queiroz”, 2005. p. 139153.

OKON LEVY, N. et al. Induced resistance to foliar diseases by soil solarization and Trichoderma harzianum. Plant Pathology, Edgmond, v. 64, n. 2, p. 365-374, June. 2015.

PEIXOTO, P. H. P. et al. Aluminum effects on lipid peroxidation andon the activities of enzymes of oxidative metabolism in sorghum. Revista Brasileira de Fisiologia Vegetal, Campinas, v. 11, n. 3, p. 137143, Aug. 1999.

RESENDE, M. L. V. et al. Produtos comerciais à base de bioindutores de resistência em plantas. Revisão Anual de Patologia de Plantas, Passo Fundo, v. 14, p. 361-380, Oct. 2006.

RODRIGUES, L. M. R. et al. Agressiveness of Pseudomonas syringae pv. garcae strains in Coffea arabica cvs. Mundo Novo and Borboun Amarelo. Abstracts, International Conference on Coffee Science, San José: ASIC, p. 199, 2012. 
RODRÍGUEZ, G. A. A. et al. Phialomyces macrosporus decreases anthracnose severity on coffee seedlings by competition for nutrients and induced resistance. Biological Control, Wageningen, v. 103, p. 119-128, Dec. 2016.

ROMANAZZI, G. et al. Integrated management of postharvest gray mold on fruit crops. Postharvest Biology and Technology, Potsdam, v. 113, p. 69-76. Mar. 2016.

SERA, G. H. et al. Associação de Pseudomonas syringae pv. garcae com algumas características agronômicas em cafeeiros F2 segregantes para o gene erecta. Ciência e Agrotecnologia, Lavras, v. 28, n. 5, p. 974-977, Oct. 2004.

SERA, T.; ALTEIA, M. Z.; PETEK, M. R. Melhoramento do cafeeiro: variedades melhoradas no Instituto Agronômico do Paraná (IAPAR). In: ZAMBOLIM, L.O estado da arte de tecnologias na produção de café. Viçosa: UFV, 2002, p. 217-251.

SHANNER, G.; FINNEY, R. F. The effect of nitrogen fertilization on the expression of slow-mildewing resistance in knox wheat. Phytopathology, Saint Paul, v. 67 , n. 8 , p. 1051-1056, Feb. 1977.

SIDHU, G. S.; WEBSTER, J. M. The use of amino acid fungal auxotrophs to study the predisposition phenomena in the root-knot: wilt fungus disease complex. Physiological Plant Pathology, London, v. 11, n. 11, p. 117-127, Sept, 1977.
SPADARO, D.; DROBY, S. Development of biocontrol products for postharvest diseases of fruit: the importance of elucidating the mechanisms of action of yeast antagonists. Trends in Food Science \& Technology, London, v. 47, p. 39-49, Jan. 2016.

THALER, J. S.; OWEN, B.; HIGGINS, V. J. The role of the jasmonate response in plant susceptibility to diverse pathogens with a range of lifestyles. Plant physiology, Bronx, v. 135, n. 1, p. 530-538, May. 2004.

WALLING, L. L. Induced resistance: from the basic to the applied. Trends in plant science, Hampshire, v. 6, n. 10 , p. $445-447$, Oct. 2001.

WANG, X. et al. Biocontrol and plant growthpromoting activity of rhizobacteria from Chinese fields with contaminated soils. Microbial biotechnology, Barcelona, v. 8, n. 3, p. 404-418, Sept. 2015.

ZHANG, Q. et al. Streptomyces rochei A-1 induces resistance and defense-related responses against Botryosphaeria dothidea in apple fruit during storage. Postharvest Biology and Technology, Leuven, v. 115, p. 30-37, May. 2016.

ZOCCOLI, D. M.; TAKATSU, A.; UESUGI, C. H. Ocorrência de mancha aureolada em cafeeiros na região do Triângulo Mineiro e Alto Paranaíba. Bragantia, Campinas, v. 70, n. 4, p. 843-849, Apr. 2011. 